\title{
WABAH DAN PERINGATAN PERJALANAN \\ DALAM PERSEPSI WISATAWAN
}

\author{
Imam Nur Hakim \\ Direktorat Kajian Strategis \\ Kementerian Pariwisata \& Ekonomi Kreatif \\ E-mail: imamnurhakim@kemenpar.go.id
}

\begin{abstract}
Travel risk factors are always becoming tourist considerations to make decisions. The most important travel risks are health problems and the disease that exist in the destination. That existence often affects the perception of tourists. This perception is also exacerbated by the emergence of travel warnings issued by related institutions. Thus, perceptions of travel risks and travel warnings simultaneously influence travelers' decisions. Using a descriptive qualitative approach through a literature review, this study found several internal and external indicators that influence tourist perceptions of disease, as well as indicators that influence their perception of travel warnings as an emphasis on the current situation that occurs in affected tourist destinations. These indicators need to be considered as an effort to respond and restore the situation if Indonesia is later affected by a disease and travel warnings.
\end{abstract}

Keywords: Disease, Travel Warnings, Travel Risk, Tourism

\section{Pendahuluan}

Setiap perjalanan wisata, identik dan tidak pernah lepas dari kemungkinan risiko yang akan dijumpai. Mulai dari keberangkatan hingga kembalinya wisatawan ketempat asal. Namun, tidak semua risiko tersebut dipersepsikan dan dipahami sama oleh wisatawan. Perbedaan ini penting untuk dipahami, karena persepsi terhadap risiko, secara langsung memengaruhi keputusan wisatawan dalam memilih destinasi tujuan wisata (Garg, 2013). Pada dasarnya. kecenderungan menghindari risiko muncul karena adanya kebutuhan wisatawan untuk mendapatkan keselamatan, kedamaian, dan stabilitas saat memilih tujuan perjalanan (Garg, 2013). Mereka lebih 
memprioritaskan komponen tersebut dalam memilih destinasi tujuan wisata dan menghindari faktor lain yang mengeliminasi kebutuhan tersebut. Salah satu yang menjadi penghalang adalah keberadaan wabah dan masalah kesehatan. Masalah kesehatan, wabah dan pariwisata merupakan bagian integral dari "pengalaman wisata" yang memengaruhi kepuasan dan kualitas hidup wisatawan (Lawton \& Page, 1997 dalam Maditinos \& Vassiliadis, 2008). Sehingga permasalahan wabah dan kesehatan tidak pernah lepas dari pertimbangan wisatawan selama proses mengambil keputusan.

Sejak beberapa dekade silam, kemunculan wabah dan masalah kesehatan berdampak signifikan terhadap sektor pariwisata, terutama jika destinasinya terkena wabah dan masalah kesehatan. Sebagai contoh, Wabah MERS-CoV di Korea setidaknya menghilangkan 2,1 Juta kunjungan atau setara dengan US\$ 2.6 Juta kerugian pendapatan devisa pariwisata (Joo et al., 2019; Keogh-Brown and Smith, 2008). Pada kasus wabah SARS, negara terdampak seperti China, Hongkong, Vietnam, dan Singapore, juga mengalami kehilangan rata-rata US\$ 20 Juta serta hilangnya 3 juta pekerjaan dibidang pariwisata (WTTC, 2003 dalam Rosselló et al., 2017). Demikian sebaliknya, upaya untuk memberantas wabah dapat meningkatkan kembali performa sektor pariwisata. Upaya pemberantasan wabah Dengue, Malaria, Yellow Fever dan Ebola, telah mengembalikan setidaknya 10 juta wisatawan di seluruh dunia serta meningkatkan devisa sebesar US\$ 12 Juta (Rosselló et al., 2017). Namun, tidak semua wabah, secara global berpengaruh terhadap penurunan angka kunjungan wisatawan (Rosselló et al., 2017). Seperti pada wabah Avian Flu yang tidak berdampak signifikan pada pariwisata global (Kuo, Chen, Tseng, Ju, \& Huang, 2008; Cooper, 2005; McAleer, Huang, Kuo, Chen, \& Chang, 2010). Artinya, tidak semua keberadaan wabah memengaruhi sikap wisatawan dalam mengambil keputusan berwisata. Perbedaan sikap terhadap wabah yang terjadi dalam perbedaan rentang waktu tersebut mengindikasikan adanya perbedaan persepsi wisatawan. 
Secara khusus, keberadaan wabah dan masalah kesehatan di destinasi wisata tujuan, membuat lembaga terkait, memberikan perhatian berupa peringatan perjalanan bagi wisatawan. Peringatan perjalanan tersebut biasa disebut travel warning, travel alert, travel advice maupun travel advisories. Peringatan perjalanan, pada dasarnya ditujukan untuk melindungi wisatawan dari ancaman yang serius (Mylonopoulos et al., 2016b). Kebijakan ini seringkali dikeluarkan oleh negara (Zuckerman and Leggat, 2006) dan lembaga berwenang lain (Mylonopoulos et al., 2016b) sebagai implementasi dari kewajibannya untuk melindungi warga negaranya dari potensi ancaman (Arsika et al., 2018). Bentuknya yang berjenjang sesuai tingkat keparahan, membuat peringatan perjalanan ini secara dinamis memiliki pengaruh dan efek yang berbeda. Menurut Noble, kebijakan peringatan perjalanan dapat memengaruhi kepatuhan atas keyakinan, niat, dan sikap wisatawan (Noble et al., 2012). Artinya unsur peringatan perjalanan memengaruhi keputusan perjalanan wisatawan melalui perubahan persepsi mereka terhadap destinasi wisata terdampak. Kajian ini bertujuan untuk menemukan faktor yang dapat memengaruhi persepsi wisatawan saat destinasi tujuan wisatanya terdampak wabah dan peringatan perjalanan. Hadirnya wabah telah menjadi kekhawatiran potensial wisatawan terhadap kesehatan mereka (Maditinos and Vassiliadis, 2008). Adanya peningkatan perjalanan ke negara-negara tropis (termasuk Indonesia), juga membuat peran konsultasi terkait kesehatan semakin dibutuhkan wisatawan. Sehingga faktor-faktor yang memengaruhi persepsi wisatawan terhadap destinasi terdampak seperti persepsi risiko terhadap wabah, kebutuhan untuk pencegahan, manajemen penyakit ketika bepergian serta prioritas keselamatan pribadi wisatawan, semakin dibutuhkan oleh (Rack et al., 2006). Dengan menemukan indikator pembentuk persepsi tersebut, pemangku kepentingan dapat segera mengetahui respon pasar terhadap wabah dan peringatan perjalanan saat Indonesia terdampak, serta menentukan strategi penetrasi pasar sebagai upaya pemulihan paska wabah. 


\section{Metode}

Kajian ini menggunakan pendekatan kualitatif dengan model analisis deskriptif. Pendekatan ini dilakukan dengan mengumpulkan literasi terkait tema dan mengkategorikannya dalam kelompok indikator berpengaruh. Kajian ini menggunakan referensi ilmiah sekunder dalam bentuk jurnal, buku, prosiding dan rujukan ilmiah terkait lainnya sebagai sumber data. Penulis menginduksi 21 artikel ilmiah dari 16 jurnal internasional, 1 buku dan 1 prosiding seminar internasional selama periode 2003 hingga 2019, mengingat beberapa kejadian wabah terjadi dalam kurun waktu tersebut. Kajian ini bertujuan untuk mengetahui indikator yang memengaruhi persepsi wisatawan terhadap wabah dan peringatan perjalanan.

\section{Pembahasan}

Setiap perjalanan wisata, tidak lepas dari kemungkinan risiko yang akan dijumpai. Secara umum terdapat dua jenis risiko yang dinilai oleh wisatawan selama perjalanan, yaitu risiko yang datang dari destinasi tujuan dan risiko dari diri wisatawan (WHO, 2012 dalam Leggat \& Franklin, 2013). Setiap risiko memiliki pengaruh terhadap persepsi wisatawan dan disebabkan oleh beragam faktor (Albattat, 2017; Uraiporn and E., 2009). Diantara risiko yang ditemui selama berwisata, faktor kesehatan dan penerimaan risiko wisatawan terkait kesehatan menjadi penentu yang paling dipertimbangkan (Steffen et al., 2003). Isu kesehatan dan risiko terpapar wabah menjadi bahan pertimbangan wisatawan dalam menentukan aman tidaknya destinasi untuk dikunjungi. Ditambah, isu kesehatan dan wabah di destinasi wisata menjadi krusial belakangan ini. Perjalanan wisata berpotensi menciptakan masalah global. Hal ini karena pergerakan antar negara berisiko besar memicu masalah kesehatan dan penularan wabah dari asal maupun tujuan wisatawan (Albattat, 2017; LaRocque et. Al., 2012). 
Kenaikan signifikan perjalanan wisatawan, secara epidemiologis, juga menempatkan wisatawan sebagai kelompok yang paling rentan terkena beragam penyakit (LaRocque et al., 2012) dari berbagai sebab (Angell and Cetron, 2005; Callahan and Hamer, 2005; Chen et al., 2009; Freedman et al., 2006; Kotton et al., 2005), sehingga membuat mereka mencari nasihat perjalanan terkait kesehatan dan wabah sebelum berwisata (Dahlgren et al., 2006). Meskipun demikian, tidak semua wisatawan memiliki tingkat kesadaran risiko yang sama. Beberapa dari mereka tidak melakukan persiapan ketika berkunjung ke destinasi terdampak (Rack et al., 2006), sebagian lainnya memiliki tingkat kesadaran terhadap risiko wabah yang tinggi dan membuat mereka lebih siap untuk berkunjung (CHUO, 2007; Pennings et al., 2002). Hal ini menunjukkan adanya perbedaan perilaku saat masa krisis terjadi yang dipicu keragaman tingkat persepsi dan sikap wisatawan terhadap risiko (Pennings et al., 2002). Sehingga, penting untuk memahami persepsi risiko wisatawan terhadap wabah.

\section{Persepsi Risiko Terhadap Wabah}

Persepsi risiko menjadi pertimbangan keputusan perjalanan wisatawan (Reisinger and Mavondo, 2006). Demikian juga terhadap risiko terkait wabah. Risiko ini membentuk dan membedakan persepsi wisatawan secara internal dan eksternal. Faktor internal berkaitan dengan persepsi individu wisatawan terhadap risiko wabah dan kesehatan. Sedangkan faktor eksternal meliputi persepsi wisatawan terhadap destinasi tujuan wisata. Penulis mendapati beberapa indikator yang memengaruhi persepsi risiko wisatawan terhadap wabah, diantaranya: 
Tabel 1. Indikator yang memengaruhi persepsi risiko wisatawan terhadap wabah

\begin{tabular}{|c|c|c|c|}
\hline \multicolumn{2}{|c|}{ Internal } & \multicolumn{2}{|c|}{ Eksternal } \\
\hline Indikator & Sumber & Indikator & Sumber \\
\hline Jenis Wabah & WHO, 2012 & $\begin{array}{c}\text { Kondisi Destinasi } \\
\text { Tujuan }\end{array}$ & $\begin{array}{l}\text { Mylonopoulos, Moira, } \\
\text { \& Papagrigoriou, } 2016\end{array}$ \\
\hline Tingkat Risiko & Zimmer, 2012 & $\begin{array}{c}\text { Keberadaan Fasilitas } \\
\text { Perawatan Medis }\end{array}$ & $\begin{array}{l}\text { Mylonopoulos, Moira, } \\
\text { \& Papagrigoriou, } 2016\end{array}$ \\
\hline $\begin{array}{c}\text { Perubahan Tingkat } \\
\text { Risiko }\end{array}$ & $\begin{array}{l}\text { Mylonopoulos, Moira, } \\
\text { \& Papagrigoriou, } 2016\end{array}$ & $\begin{array}{l}\text { Keberadaan Dan } \\
\text { Lokasi Wabah }\end{array}$ & Rosselló et al., 2017 \\
\hline Usia & Rack et al., 2006 & $\begin{array}{l}\text { Kondisi Kehidupan } \\
\text { Destinasi Tujuan }\end{array}$ & $\begin{array}{l}\text { Mylonopoulos, Moira, } \\
\text { \& Papagrigoriou, } 2016\end{array}$ \\
\hline $\begin{array}{l}\text { Kondisi Kesehatan } \\
\text { Wisatawan }\end{array}$ & $\begin{array}{l}\text { R. C. LaRocque et al., } \\
\text { 2011; Kotton et al., } \\
\text { 2005; (Hill et al., 2006) }\end{array}$ & Unfiltered Information & Kim \& Kim, 2018 \\
\hline $\begin{array}{c}\text { Kondisi Negara } \\
\text { Wisatawan }\end{array}$ & Rosselló et al., 2017 & Exposure Media Sosial & Kim \& Kim, 2018 \\
\hline Durasi Berkunjung & $\begin{array}{l}\text { Rack et al., 2006; Chen } \\
\text { et al., 2009; Callahan \& } \\
\text { Hamer, } 2005\end{array}$ & Konten Media & Yang \& Cho, 2017 \\
\hline Tujuan Wisata & Angell \& Cetron, 2005 & Lokasi Wisata & WHO, 2012 \\
\hline Status Vaksinasi & WHO, 2012 & Musim & WHO, 2012 \\
\hline $\begin{array}{l}\text { Tingkat Risiko } \\
\text { Tertular }\end{array}$ & WHO, 2012 & Panjangnya Paparan & WHO, 2012 \\
\hline Tingkat Ancaman & $\begin{array}{l}\text { Leggat \& Franklin, } \\
2013\end{array}$ & $\begin{array}{c}\text { Aktivitas dan Jenis } \\
\text { Wisata, }\end{array}$ & WHO, 2012 \\
\hline $\begin{array}{c}\text { Kemampuan } \\
\text { Mengukur Risiko } \\
\text { Wisata }\end{array}$ & Zimmer, 2012 & & \\
\hline $\begin{array}{l}\text { Pengalaman } \\
\text { Berkunjung }\end{array}$ & $\begin{array}{c}\text { Zimmermann, } \\
\text { Hattendorf, Blum, } \\
\text { Nüesch, \& Hatz, } 2013\end{array}$ & & \\
\hline
\end{tabular}

Usia dan durasi berkunjung menjadi faktor internal yang memengaruhi persepsi risiko terhadap wabah. Wisatawan berusia muda dan berkunjung dengan durasi lama, lebih rentan terdampak risiko kesehatan selama perjalanan (Rack et al., 
2006; Chen et al., 2009; Callahan \& Hamer, 2005). Selain itu, wisatawan yang berkunjung lebih lama, membutuhkan lebih banyak edukasi terkait kesehatan, vaksinasi dan pengobatan pribadi dibandingkan wisatawan jangka pendek (Callahan \& Hamer, 2005). Ini menandakan, kondisi kesehatan terkini (R. C. LaRocque et al., 2011; Kotton et al., 2005; Hill et al., 2006) dan vaksinasi (WHO, 2012 dalam Rosselló et al., 2017) menjadi pertimbangan yang memengaruhi persepsi mereka sebelum melakukan perjalanan. Artinya, wisatawan dengan kondisi kesehatan yang baik, telah melakukan vaksinasi, tidak berusia muda dan berwisata dengan durasi singkat, berpeluang lebih besar untuk berkunjung ke destinasi (paska) terdampak wabah.

Faktor internal lain yang menjadi penentu perjalanan adalah tujuan wisata (Angell \& Cetron, 2005) dan pengalaman berkunjung sebelumnya (Zimmermann et al., 2013). Meskipun keberadaan wabah, menjadi risiko yang diperhitungkan wisatawan dalam memilih tujuan wisata (Rosselló et al., 2017), seringkali wisatawan yang memiliki riwayat berkunjung di destinasi terdampak, bersikap acuh dan datang tanpa persiapan. Mereka menganggap telah mengerti apa yang harus dilakukan (Dahlgren et al., 2006) dan tidak merubah persepsi risiko antara sebelum dan sesudah perjalanan, sampai mereka mengalami hal serupa di tempat tersebut (Zimmermann et al., 2013). Sehingga, wisatawan repeater dengan tingkat traumatis yang rendah (tidak memiliki pengalaman terdampak wabah sebelumnya) dapat menjadi prioritas pasar.

Jenis wabah juga menjadi faktor penting yang memengaruhi persepsi wisatawan terhadap risiko tertular dari waktu ke waktu (WHO, 2012 dalam Rosselló et al., 2017; Zimmer, 2012), risiko saat berwisata (WHO, 2012 dalam Rosselló et al., 2017), perubahan status risiko (Mylonopoulos et al., 2016), serta tingkat ancaman tertular (Leggat, 2013). Hubungan ini tampak pada perubahan sikap wisatawan dalam mengambil keputusan dan melakukan tindakan yang diperlukan. Artinya, semakin tinggi tingkat ancaman, pemahaman risiko tertular secara umum (dan saat berwisata), serta semakin baik kemampuan wisatawan dalam mengukur risiko 
wabah, maka akan semakin memengaruhi persepsi mereka dalam menentukan keputusan untuk berkunjung. Sifatnya yang dinamis, menjadikan setiap jenis wabah memengaruhi persepsi wisatawan sesuai perbedaan latar belakang termasuk asal mereka. Wisatawan dari negara maju, lebih sensitif terhadap risiko yang dijelaskan sebelumnya (Rosselló et al., 2017). Bahkan, negara dengan risiko wabah atau penyakit dapat memberi dampak negatif kepada negara tetangganya (Rosselló et al., 2017). Artinya, jika Indonesia terdampak wabah, maka wisatawan dari negara tetangga yang masuk dalam kategori negara maju akan lebih sensitif serta terpengaruh dibandingkan wisatawan yang datang dari negara berkembang dan jauh.

Dari sisi eksternal, beberapa hal terkait destinasi tujuan, dipertimbangkan wisatawan saat akan berkunjung ke destinasi terdampak wabah. Pertimbangan tersebut dapat dibedakan dari dua sudut pandang, yaitu sudut pandang destinasi tujuan, serta sebaran informasi tentang destinasi tujuan.

Dari sudut pandang destinasi tujuan, keberadaan wabah di destinasi, lokasi destinasi terdampak, musim berlangsung, jenis aktivitas wisata dan panjangnya paparan wabah diadaptasi dari penelitian Rosello (2017) dan WHO (2012). Sedangkan kondisi kehidupan di destinasi tujuan, tingkat higienitas, serta keberadaan fasilitas perawatan medis, diambil dari penelitian Mylonopoulos, et, al. (2016).

Keberadaan dan lokasi destinasi terdampak wabah, menjadi pertimbangan eksternal yang penting. Bahkan, keberadaan wabah seringkali menjadi sebab turunnya angka kunjungan wisatawan (Rosselló et al., 2017) seperti yang terjadi akibat wabah SARS di China, Hongkong, Vietnam dan Singapore (WTTC, 2003 dalam Rosselló et al., 2017). Namun pada beberapa kasus, seperti Avian flu, keberadaannya tidak memengaruhi pariwisata global secara signifikan (Kuo, Chen, Tseng, Ju, \& Huang, 2008; Cooper, 2005; McAleer, Huang, Kuo, Chen, \& Chang, 2010) dan hanya memengaruhi wilayah dimana wabah tersebut terjadi (Kuo et al., 2007). Menurut WHO (2012), panjangnya paparan wabah di destinasi juga memengaruhi persepsi wisatawan. Wabah dengan paparan yang lebih panjang akan memberikan lebih 
banyak dampak. Begitu juga lokasi dan sebaran wabah seperti perbandingan antara SARS dan Avian flu sebelumnya, Semakin global sebaran wabah, semakin massif dampaknya. Indikator ini penting untuk menentukan langkah pemulihan paska wabah. Dimana destinasi yang terdampak paling parah dan lama, perlu melakukan upaya pemulihan paling intensif sebelum dipromosikan kembali. Sebaliknya, destinasi yang terdampak paling ringan dan pulih dengan cepat, dapat lebih dulu dipromosikan. Dengan asumsi, bahwa wisatawan lebih memilih destinasi yang tidak terdampak wabah dibandingkan yang terdampak atau terdampak lebih parah.

Aktifitas wisata dan musim yang sedang berlangsung, juga memengaruhi persepi wisatawan terkait wabah. Saat terjadi wabah, lazimnya, aktifitas wisata akan dibatasi. Namun, terdapat kelompok yang cenderung terbuka dan paling tertutup menghadapi situasi ini. Kelompok yang cenderung terbuka adalah wisatawan dengan tujuan wisata visiting friend $\mathcal{E}$ relatives (VFR). Wisatawan jenis ini lebih mungkin untuk berkunjung ke negara asalnya meskipun dengan risiko kesehatan yang potensial (Angell and Cetron, 2005). Sehingga, wisatawan dengan tujuan VFR diasumsikan lebih mudah beradaptasi dengan wabah. Artinya, kampanye untuk kembali mengunjungi rekan dan keluarga dapat dijadikan solusi pemasaran paska pemulihan. Sebaliknya, kelompok yang paling tertutup adalah wisatawan dengan riwayat transplantasi organ tubuh (SOT). Wisatawan dengan riwayat SOT memiliki kebutuhan dan tingkat penerimaan risiko yang lebih kompleks. Mereka lebih selektif dan detail dalam mempersepsikan pencegahan wabah dibandingkan jenis wisatawan lain (Kotton et al., 2005). Menurut Kotton et al. (2005), mereka masuk dalam kategori wisatawan yang paling rentan dengan gangguan kesehatan serta banyak menghindari aktifitas wisata tertentu. Sehingga kelompok ini tidak relevan untuk menjadi prioritas pasar paska wabah.

Faktor eksternal lain yang memengaruhi persepsi wisatawan, adalah kondisi kehidupan, tingkat higienitas dan keberadaan fasilitas perawatan medis di destinasi tujuan. Menurut Mylonopoulos, et, al. (2016) ketiga faktor ini menjadi indikator yang 
dipertimbangkan wisatawan. Pemangku kepentingan pariwisata, perlu mempertimbangkan faktor tersebut dalam upaya pencegahan, pengendalian dan pemulihan destinasi paska wabah. Jika dihubungkan dengan indikator Health and Hygiene dalam The Travel E Tourism Competitiveness Report 2019 (WEF, 2019), sebagai alat ukur pencapaian pariwisata global, maka jumlah dokter dalam setiap 1000 populasi, jumlah kamar perawatan dalam setiap 10.000 populasi, dapat mewakili komponen untuk menjawab keberadaan fasilitas perawatan medis, sedangkan kebersihan sanitasi dan air minum serta sedikitnya jumlah penyakit wabah, dapat menjadi komponen untuk menjawab kondisi kehidupan dan tingkat higienitas suatu negara, khususnya destinasi pariwisata.

Sebaran informasi di destinasi tujuan juga menjadi faktor eksternal yang dipertimbangkan. Di masa wabah, keberadaan informasi yang "unfiltered", tingkat kekuatan social media exposure dari destinasi wisata serta konten media yang dipakai, dapat memengaruhi persepsi wisatawan. Ketiga indikator tersebut diadaptasi dari penelitian Kim \& Kim (2018) dan Yang \& Cho (2017).

Umumnya, wisatawan akan mencari informasi tentang destinasi tujuan sebelum berangkat. Dalam tahap ini, media berperan secara makro untuk meningkatkan kepercayaan dan persepsi publik terhadap keamanan negara tujuan melalui kampanye media massa (Mao et al., 2010). Namun, banyaknya informasi, tidak selalu berbanding lurus dengan tingkat pemahaman risiko wisatawan. Pada kasus wabah MERS, informasi yang tidak terfilter, berpotensi meningkatkan ketakutan berlebihan terhadap wabah (Kim and Kim, 2018). Hal ini disebabkan karena ketidakjelasan informasi, beralih fungsi menjadi rumor dan menghasilkan ketakutan berlebihan yang tidak perlu. Perlu ada pemahaman terintegrasi agar media memberitakan konten yang informatif dan membangun. Sehingga, media massa secara konsisten dapat membangun kepercayaan internasional, mulai dari transparansi ketika terjangkit, keterbukaan ketika menangani, hingga kejujuran saat wabah telah hilang dari destinasi. Pemangku kepentingan juga perlu mengedukasi 40 JUMPA Volume 7, Nomor 1, Juli 2020 
masyarakat untuk mengonsumsi dan menyebarkan informasi kredibel terkait wabah. Pergerakan informasi yang dikonsumsi dan disebarkan melalui konten media sosial secara global, bukan hanya dapat memengaruhi persepsi seseorang terhadap risiko (Kim and Kim, 2018), namun juga reaksi dan sikap wisatawan terhadap wabah (Yang and Cho, 2017). Artinya, konten yang disebar melalui media sosial, sangat memengaruhi pandangan wisatawan terhadap Indonesia, khususnya destinasi wisata tujuan. Terlebih, media sosial dan internet menjadi rujukan wisatawan untuk mendapatkan rekomendasi terkait kesehatan dan wabah sebelum berwisata (Dahlgren et al., 2006; R. LaRocque et al., 2010).

\section{Persepsi Risiko Terhadap Peringatan Perjalanan Terkait Wabah}

Selain individu, persepsi risiko terhadap wabah, juga diterjemahkan oleh pengambil kebijakan dalam bentuk tindakan preventif maupun antisipatif. Tindakan ini disebut "peringatan perjalanan" (Beirman, 2006). Peringatan tersebut bisa berjangka waktu pendek maupun panjang dan memiliki beragam tingkatan keparahan. Beberapa penamaan yang lazim digunakan diantaranya travel warning, travel alert, travel advice dan travel advisories.

Pada dasarnya, peringatan perjalanan ditujukan untuk melindungi wisatawan dari ancaman serius (Mylonopoulos et al., 2016b). Kebijakan ini seringkali dikeluarkan oleh negara (Zuckerman and Leggat, 2006), sebagai kewajiban untuk melindungi warga negaranya dari berbagai potensi ancaman (Arsika et al., 2018). Peringatan perjalanan biasanya merupakan pemberitahuan resmi yang dikeluarkan pemerintah kepada warga negaranya dalam bentuk imbauan/larangan untuk tidak bepergian ke negara atau wilayah tertentu dalam rangka merespon situasi berbahaya yang sedang terjadi (Arsika et al., 2018). Selain negara, peringatan perjalanan serupa juga diberikan oleh lembaga berwenang lain (Mylonopoulos et al., 2016b) seperti lembaga kesehatan dan lembaga terkait isu yang dihadapai. Rekomendasi peringatan 
perjalanan oleh lembaga kesehatan ini sering kali dijadikan rujukan, bukan hanya oleh wisatawan sebagai individu, namun juga oleh negara.

Jika persepsi wisatawan terhadap risiko wabah, secara internal dan eksternal memengaruhi cara pandang mereka terhadap destinasi tujuan, maka rekomendasi yang dikeluarkan melalui kebijakan peringatan perjalanan, juga dapat memengaruhi kepatuhan atas keyakinan, niat, dan sikap wisatawan (Noble et al., 2012). Artinya, unsur peringatan perjalanan menjadi pertimbangan wisatawan. Meskipun, seringkali keberadaannya memperburuk stigma mereka terhadap destinasi tujuan terdampak wabah. Bahkan, keberadaan peringatan perjalanan terkait wabah sering menjadi sebab adanya pembatasan dan pelarangan arus perjalanan wisata (Mylonopoulos et al., 2016b). Indikator yang memengaruhi persepsi wisatawan terhadap peringatan perjalanan terkait wabah, selanjutnya dikategorikan sebagai berikut:

Tabel 2. Indikator yang memengaruhi persepsi risiko wisatawan terhadap peringatan perjalanan terkait wabah

\section{Indikator Persepsi Risiko Terhadap Peringatan Perjalanan Terkait Wabah}

Indikator

Persepsi Wisatawan terhadap Risiko

Pemahaman dan Kekhawatiran tentang Risiko

\section{Sumber}

Leggat \& Franklin, 2013; Noble et al., 2012a

Leggat \& Franklin, 2013; Noble et al., 2012a

Pilihan Strategi Pengelolaan Risiko Leggat \& Franklin, 2013; Noble et al., 2012a

Lembaga yang Mengeluarkan Peringatan Perjalanan

Mylonopoulos, Moira, \& Kikilia, 2016

Kesadaran, Pengetahuan, dan Pemanfaatan

Paris, 2013 dan Global Sources, 2014 dalam

Peringatan Perjalanan

Tsang, Wong, \& Prideaux, 2018

Kualitas dan kredibilitas Informasi

Peringatan Perjalanan

Tsang, Wong, \& Prideaux, 2018

Penekanan Media (Nasional dan Global)

Mylonopoulos, Moira, \& Papagrigoriou, 2016; Page, 2009

Keberadaan Asuransi Perjalanan

Page, 2009; Tsang, Wong, \& Prideaux, 2018 
Respon wisatawan terhadap peringatan perjalanan terkait wabah dipengaruhi oleh beberapa hal, diantaranya, persepsi terhadap risiko, pemahaman dan kekhawatiran tentang risiko serta pilihan strategi pengelolaan risiko yang diambil (Leggat \& Franklin, 2013). Sebagaimana dibahas sebelumnya, persepsi wisatawan terkait risiko wabah, memainkan peran penting dalam memengaruhi cara pandang wisatawan terhadap destinasi tujuan. Persepsi tersebut seringkali melebihi kondisi aktualnya saat destinasi juga terdampak peringatan perjalanan. Persepsi risiko terhadap peringatan perjalanan juga dipengaruhi oleh pemahaman dan tingkat kekawatiran, serta kemampuan wisatawan mengendalikan wabah. Disamping itu, kecenderungan untuk menghindari destinasi terdampak diperparah dengan absennya asuransi perjalanan (Page, 2009). Saat terjadi wabah, wisatawan cenderung memperhatikan ketersediaan polis asuransi. Artinya, peringatan perjalanan terkait wabah hanya akan berdampak pada wisatawan yang paham bagaimana wabah tersebut membahayakan mereka. Namun, mereka yang paham, dan tetap memutuskan untuk berangkat, adalah wisatawan yang memahami cara mengendalikan risiko wabah, seperti pencegahan, perawatan, ketersediaan asuransi serta strategi dalam mengelola risiko terkait wabah.

Persepsi terhadap peringatan perjalanan terkait wabah juga dipengaruhi oleh lembaga yang mengeluarkan peringatan dan formalitas tingkat peringatan (Mylonopoulos et al., 2016a), kualitas informasi peringatan (Rack et al., 2006) serta kredibilitas informasi peringatan dari sudut pandang wisatawan (Monterrubio, 2013). Semakin kredibel sebuah lembaga yang mengeluarkan peringatan perjalanan, semakin formal konten peringatannya, semakin berkualitas informasi yang disampaikan, maka semakin patuh wisatawan terhadap peringatan perjalanan tersebut.

Umumnya, peringatan perjalanan dikeluarkan oleh negara asal wisatawan, sebagai kewajiban untuk melindungi warganya. Peringatan perjalanan ini dirumuskan bersama kementerian terkait dan memiliki perbedaan tingkat keparahan 
yang menjadikan peringatan ini juga memiliki perbedaan tingkat kelonggaran. Semakin tinggi peringatan (level 4 atau warna hitam), semakin mengharuskan warganya untuk meninggalkan destinasi maupun membatalkan perjalanannya ke negara tersebut (Mylonopoulos et al., 2016a). Selain negara, pihak pemberi peringatan perjalanan terkait wabah lainnya adalah tenaga medis dan lembaga kesehatan. Berbeda dengan peringatan perjalanan negara, peringatan perjalanan oleh tenaga medis (termasuk apoteker) bertujuan agar wisatawan mengetahui risiko yang mungkin dihadapi saat melakukan perjalanan (Ziegler, 2013; Kodkani et al., 2008). Peringatan tersebut mempertimbangkan beberapa faktor preventif seperti pendampingan pelatihan kesehatan, pengetahuan tentang risiko kesehatan, pemberian informasi terbaru seputar wabah serta penanganannya (vaksinasi) hingga informasi tempat berobat di destinasi tujuan (Ziegler, 2013). Lembaga kesehatan global juga berperan di lingkup eksternal sebagai pihak berwenang lain yang mengeluarkan peringatan perjalanan. Terdapat beberapa lembaga kesehatan internasional yang rutin mengeluarkan rekomendasi kesehatan sebagai tindakan preventif, seperti CDC, WHO dan lembaga terkait lainnya. Indonesia dapat merujuk lembaga tersebut, untuk mengetahui kemungkinan potensi penyebaran wabah, hingga lebih lanjut menganalisis dampaknya terhadap sirkulasi wisatawan.

Seluruh lembaga berwenang yang mengeluarkan peringatan perjalanan tersebut, tidak secara sama dianggap setara oleh wisatawan, sehingga menimbulkan perbedaan persepsi terhadap kualitas informasi (Rack et al., 2006) serta kredibilitasnya (Monterrubio, 2013). Peringatan perjalanan resmi, lebih dapat dipercaya dibandingkan sumber organik lainnya (Monterrubio, 2013). Namun dalam prosedurnya, seringkali media membuat ukuran keparahan tersebut melebihi keadaan yang sebenarnya. Penekanan Media dalam fungsinya sebagai penyebar informasi peringatan perjalanan, menjadi pertimbangan penting dalam memengaruhi persepsi wisatawan (Page, 2009). Media selalu memiliki peran untuk meng-emphasize dan melebih-lebihkan risiko aktual. Hal tersebut menjadi sebab ragunya wisatawan 
terhadap kualitas informasi peringatan perjalanan. Namun, dalam penelitian page (2009), didapati hal sebaliknya. Kecenderungan wisatawan untuk menghindari destinasi terdampak justru muncul setelah peringatan perjalanan resmi diberitakan secara massif oleh media lokal dan internasional (Page, 2009; Mylonopoulos et al., 2016). Wisatawan bahkan lebih memilih berita di televisi, platform online, atau aplikasi seluler daripada laman resmi pemerintah yang mengeluarkan peringatan perjalanan (Rack et al., 2006). Dalam hal ini, Indonesia perlu mencermati kembali sejauh mana peran media dalam memengaruhi persepsi risiko wisatawan terhadap peringatan perjalanan. Perbedaan antara wisatawan dari asal negara, tingkat pendidikan, budaya dan indikator lainnya bisa jadi membedakan cara mereka mempresepsikan kualitas peringatan tersebut.

Meskipun peringatan perjalanan ditujukan untuk meningkatkan kesadaran terhadap risiko wabah, banyak wisatawan mengacuhkan peringatan tersebut, terutama peringatan perjalanan yang dikeluarkan oleh negara (Tsang et al., 2018). Hanya sebagian kecil wisatawan di negara berkembang yang memilih untuk berkonsultasi terlebih dahulu dengan pre-travel provider sebelum melakukan perjalanan (Sanford, 2002). Bahkan, sebagian besar wisatawan tidak mengetahui risiko kesehatan selama perjalanan. Dalam penelitian Rack, 50\% wisatawan tidak mengerti risiko perjalanan yang akan dihadapi. Sedangkan, hanya 14\% yang mengerti dan berkonsultasi dengan penasehat perjalanan (Rack et al., 2006). Di Inggris, penelitian serupa mengungkapkan bahwa sembilan dari sepuluh responden tidak mengetahui peringatan perjalanan yang dikeluarkan pemerintah, sementara setengah dari responden menyatakan bahwa mereka tetap melanjutkan perjalanan meskipun telah mengetahuinya (Paris, 2013 dalam Tsang et al., 2018). Hal ini menunjukkan bahwa tingkat kesadaran atas peringatan perjalanan juga memengaruhi persepsi dan sikap wisatawan terhadap keputusan mereka untuk tetap pergi dan peduli terhadap wabah di destinasi tujuan wisata. 


\section{Simpulan dan Saran}

Risiko terhadap wabah dan peringatan perjalanan, memengaruhi persepsi wisatawan terutama dalam pengambilan keputusan berkunjung. Sehingga, penting untuk memperhatikan indikator internal dan eksternal yang membentuk persepsi tersebut. Melalui indikator tersebut, pemangku kepentingan perlu melakukan upaya pemulihan yang tepat, guna meningkatkan expenditure dan pertumbuhan rata-rata secara signifikan (Rosselló et al., 2017). Pada prinsipnya, semakin cepat kembali ke situasi awal, semakin siap suatu destinasi terdampak wabah menerima kembalinya wisatawan. Untuk itu, pemahaman terhadap persepsi wisatawan terkait wabah dan peringatan perjalanan sangat diperlukan untuk menjangkau wisatawan dan melihat celah pasar secara lebih efektif. Bagian terpenting lain yang harus diperhatikan dari pemulihan paska wabah adalah mengembalikan kepercayaan wisatawan terhadap destinasi tujuan yang persepsinya berubah selama wabah berlangsung. Upaya pemulihan tersebut hanya efektif jika disertai proses yang transparan melalui pendekatan komunikasi secara masal dan individu agar wisatawan dapat melihat, mengalami dan memahami proses eliminasi risiko terkait wabah.

Pemangku kepentingan juga perlu memerhatikan kinerja media, termasuk kualitas konten, waktu persebaran informasi serta strategi penempatanya. Selain menjadi komponen yang paling masif merubah persepsi wisatawan, media juga berperan aktif dalam memengaruhi persepsi wisatawan terhadap destinasi tujuan. Perlu ada kesepahaman antar pemangku kepentingan untuk memastikan kinerja media agar selalu konsisten mendukung proses pemulihan paska wabah, di lingkup nasional dan global. Selain itu upaya pembenahan destinasi terdampak wabah juga harus dilakukan beriringan. Jika nantinya terdampak, Indonesia tidak hanya bisa mengandalkan upaya pencegahan wabah yang dilakukan wisatawan di negara asal. Karena, meskipun tersedia, hanya sedikit wisatawan yang berminat mendatangi fasilitas konsultasi kesehatan sebelum perjalanan (Kogelman et al., 2014). Perlu 
sebuah sistem untuk mengedepankan protokol kesehatan di perbatasan pintu masuk, destinasi wisata, akomodasi dan lingkup sebaran wisatawan lainnya. Penting juga untuk memastikan komponen utama seperti kelayakan perbandingan jumlah tenaga medis, jumlah kamar serta upaya pencegahan lain sebagai prioritas paska wabah. Upaya tersebut hendaknya diaplikasikan dengan baik bukan hanya di daerah perkotaan, namun juga pedesaan. Keseluruhan upaya ini dilakukan untuk terus memperbaiki dan meningkatkan citra destinasi yang sempat tergerus oleh keberadaan wabah. Karena, unsur citra dan daya tarik destinasi yang baik, menjadi pengecualian wisatawan untuk tetap berkunjung (Page, 2009). Kombinasi antara pesan citra yang tersampaikan, daya tarik destinasi dan aktifitas wisata yang menggiurkan, kesadaran tentang risiko terhadap wabah serta peringatan perjalanan yang dapat diantisipasi, menjadi output pemulihan pasar yang perlu segera diprioritaskan.

Untuk dapat mengetahui sejauh mana persepsi terhadap risiko wabah dan peringatan perjalanan secara faktual memengaruhi wisatawan, perlu dilakukan kajian lanjutan. Kajian tersebut, digunakan untuk melengkapi batasan masalah dengan menguji indikator yang ditemukan dalam kajian ini secara kuantitatif.

\section{Ucapan Terima Kasih}

Terima kasih kepada peneliti Kementerian Pariwisata dan Ekonomi Kreatif, yang telah membantu penulis untuk menemukan referensi yang relevan dan reliabel untuk kajian ini.

\section{Daftar Pustaka}

Albattat, A., 2017. Current Issue in Tourism: Diseases Transformation as a Potential Risks for Travellers.

Angell, S., Cetron, M., 2005. Health Disparities among Travelers Visiting Friends and Relatives Abroad. Ann. Intern. Med. 142, 67-72. https://doi.org/10.7326/00034819-142-1-200501040-00013 
Arsika, I., Jaya, I., Satyawati, N., 2018. Kebijakan Travel Warning dan Pembatasan Hak Berwisata. Pandecta Res. Law J. 13, 24-36. https://doi.org/10.15294/pandecta.v13i1.15115

Beirman, D., 2006. A Travel Industry Perspective on Government Travel Advisories, in: Tourism in Turbulent Times: Towards Safe Experiences for Visitors. pp. 309-319. https://doi.org/10.1016/B978-0-08-044666-0.50029-4

Callahan, M. V., Hamer, D.H., 2005. On the medical edge: preparation of expatriates, refugee and disaster relief workers, and Peace Corps volunteers. Infect. Dis. Clin. North Am. 19, 85-101. https://doi.org/10.1016/j.idc.2004.10.010

Chen, L.H., Wilson, M.E., Davis, X., Loutan, L., Schwartz, E., Keystone, J., Hale, D., Lim, P.L., McCarthy, A., Gkrania-Klotsas, E., Schlagenhauf, P., Network, G.S., 2009. Illness in long-term travelers visiting GeoSentinel clinics. Emerg. Infect. Dis. 15, 1773-1782. https://doi.org/10.3201/eid1511.090945

Chuo, H., 2007. Theme Park Visitors' Responses to the SARS Outbreak in Taiwan. Adv. Hosp. Leis., Advances in Hospitality and Leisure 3, 87-104. https://doi.org/10.1016/S1745-3542(06)03006-2

Cooper, M., 2005. Japanese Tourism and the SARS Epidemic of 2003. J. Travel Tour. Mark. 19, 117-131. https://doi.org/10.1300/J073v19n02_10

Dahlgren, A.-L., DeRoo, L., Steffen, R., 2006. Prevention of travel-related infectious diseases: Knowledge, practices and attitudes of Swedish travellers. Scand. J. Infect. Dis. 38, 1074-1080. https://doi.org/10.1080/00365540600868354

Freedman, D., Weld, L., Kozarsky, P., Fisk, T., Robins, R., Sonnenburg, F., Keystone, J., Pandey, P., Cetron, M., 2006. Spectrum of Disease and Relation to Place of Exposure among Ill Returned Travelers. N. Engl. J. Med. 354, 119-130. https://doi.org/10.1056/NEJMoa051331

Garg, A., 2013. A study of tourist perception towards travel risk factors in tourist decision making. Asian J. Tour. Hosp. Res. 7, 47-57.

Hill, D.R., Ericsson, C.D., Pearson, R.D., Keystone, J.S., Freedman, D.O., Kozarsky, P.E., DuPont, H.L., Bia, F.J., Fischer, P.R., Ryan, E.T., 2006. The Practice of Travel Medicine: Guidelines by the Infectious Diseases Society of America. Clin. Infect. Dis. 43, 1499-1539. https://doi.org/10.1086/508782

Joo, H., Maskery, B.A., Berro, A.D., Rotz, L.D., Lee, Y.-K., Brown, C.M., 2019. Economic Impact of the 2015 MERS Outbreak on the Republic of Korea's Tourism-Related Industries. Heal. Secur. 17, 100-108. https://doi.org/10.1089/hs.2018.0115

Keogh-Brown, M.R., Smith, R.D., 2008. The economic impact of SARS: How does the reality match the predictions? Health Policy (New. York). 88, 110-120. https://doi.org/https://doi.org/10.1016/j.healthpol.2008.03.003 
Kim, Sunhee, Kim, Seoyong, 2018. Exploring the Determinants of Perceived Risk of Middle East Respiratory Syndrome (MERS) in Korea. Int. J. Environ. Res. Public Health 15, 1168. https://doi.org/10.3390/ijerph15061168

Kodkani, N., Jenkins, J.M., Hatz, C.E., 2008. Travel Advice Given by Pharmacists. J. Travel Med. 6, 87-93. https://doi.org/10.1111/j.1708-8305.1999.tb00838.x

Kogelman, L., Barnett, E., Chen, L., Quinn, E., Yanni, E., Wilson, M., Benoit, C., Karchmer, A., Ooi, W., Jentes, E., Hamer, D., 2014. Knowledge, Attitudes, and Practices of US Practitioners Who Provide Pre-Travel Advice. J. Travel Med. 21. https://doi.org/10.1111/jtm.12097

Kotton, C., Ryan, E., Fishman, J., 2005. Prevention of Infection in Adult Travelers After Solid Organ Transplantation. Am. J. Transplant 5, 8-14. https://doi.org/10.1111/j.1600-6143.2004.00708.x

Kuo, H.-I., Chang, C.-L., Huang, B.-W., Chen, C.-C., McAleer, M., 2007. Avian flu and international tourism demand: A panel data analysis. MODSIM07 - Land, Water Environ. Manag. Integr. Syst. Sustain. Proc. 1892-1898.

Kuo, H.-I., Chen, C.-C., Tseng, W.-C., Ju, L.-F., Huang, B.-W., 2008. Assessing impacts of SARS and Avian Flu on international tourism demand to Asia. Tour. Manag. 29, 917-928. https://doi.org/https://doi.org/10.1016/j.tourman.2007.10.006

LaRocque, R., Rao, S., Tsibris, A., Lawton, T., Barry, M., Marano, N., Brunette, G., Yanni, E., Ryan, E., 2010. Pre-travel Health Advice-Seeking Behavior Among US International Travelers Departing From Boston Logan International Airport. J. Travel Med. 17, 387-391. https://doi.org/10.1111/j.17088305.2010.00457.x

LaRocque, R.C., Rao, S.R., Lee, J., Ansdell, V., Yates, J.A., Schwartz, B.S., Knouse, M., Cahill, J., Hagmann, S., Vinetz, J., Connor, B.A., Goad, J.A., Oladele, A., Alvarez, S., Stauffer, W., Walker, P., Kozarsky, P., Franco-Paredes, C., Dismukes, R., Rosen, J., Hynes, N.A., Jacquerioz, F., McLellan, S., Hale, D., Sofarelli, T., Schoenfeld, D., Marano, N., Brunette, G., Jentes, E.S., Yanni, E., Sotir, M.J., Ryan, E.T., 2012. Global TravEpiNet: A National Consortium of Clinics Providing Care to International Travelers-Analysis of Demographic Characteristics, Travel Destinations, and Pretravel Healthcare of High-Risk US International Travelers, 2009-2011. Clin. Infect. Dis. 54, 455-462. https://doi.org/10.1093/cid/cir839

Leggat, P., Franklin, R., 2013. Risk Perception and Travelers. J. Travel Med. 20, 1-2. https://doi.org/10.1111/j.1708-8305.2012.00663.x

Maditinos, Z., Vassiliadis, C., 2008. Crises and disasters in tourism industry: Happen locally, affect globally, in: Management of International Business E-Book. 
Mao, C.-K., Ding, C.G., Lee, H.-Y., 2010. Post-SARS tourist arrival recovery patterns: An analysis based on a catastrophe theory. Tour. Manag. 31, 855-861. https://doi.org/10.1016/j.tourman.2009.09.003

McAleer, M., Huang, B.-W., Kuo, H.-I., Chen, C.-C., Chang, C.-L., 2010. An Econometric Analysis of SARS and Avian Flu on International Tourist Arrivals to Asia. Environ. Model. Softw. 25, 100-106. https://doi.org/10.1016/j.envsoft.2009.07.015

Monterrubio, C., 2013. Destination image and crime in Mexico: An analysis of foreign government travel advice. Pasos. Rev. Tur. y Patrim. Cult. 11, 33-45. https://doi.org/10.25145/j.pasos.2013.11.036

Mylonopoulos, D., Moira, P., Kikilia, A., 2016a. The travel advice as an inhibiting factor of tourist movement. TIMS. Acta 10, 13-26. https://doi.org/10.5937/timsact10-9902

Mylonopoulos, D., Moira, P., Papagrigoriou, A., 2016b. The Travel Advisory as an Obstacle to Travel and Tourism. Case Study-The Greek Economic Crisis. Int. J. Res. Tour. Hosp. 2, 1-13.

Noble, L., Willcox, A., Behrens, R., 2012. Travel Clinic Consultation and Risk Assessment. Infect. Dis. Clin. North Am. 26, 575-593. https://doi.org/10.1016/j.idc.2012.05.007

Page, S.J., 2009. Current issue in tourism: The evolution of travel medicine research: A new research agenda for tourism? Tour. Manag. 30, 149-157. https://doi.org/https://doi.org/10.1016/j.tourman.2008.04.011

Pennings, J.M.E., Wansink, B., Meulenberg, M.T.G., 2002. A note on modeling consumer reactions to a crisis: The case of the mad cow disease. Int. J. Res. Mark. 19, 91-100. https://doi.org/https://doi.org/10.1016/S0167-8116(02)00050-2

Rack, J., Wichmann, O., Kamara, B., Günther, M., Cramer, J., Schönfeld, C., Henning, T., Schwarz, U., Mühlen, M., Weitzel, T., Friedrich-Jänicke, B., Foroutan, B., Jelinek, T., 2006. Risk and Spectrum of Diseases in Travelers to Popular Tourist Destinations. J. Travel Med. 12, 248-253. https://doi.org/10.2310/7060.2005.12502

Reisinger, Y., Mavondo, F., 2006. Cultural Differences in Travel Risk Perception. J. Travel Tour. Mark. 20, 13-31. https://doi.org/10.1300/J073v20n01_02

Rosselló, J., Santana Gallego, M., Awan, A., 2017. Infectious disease risk and international tourism demand. Health Policy Plan. 32. https://doi.org/10.1093/heapol/czw177

Sanford, C., 2002. Pre-travel advice: an overview. Prim. Care Clin. Off. Pract. 29, 767785. https://doi.org/10.1016/S0095-4543(02)00046-5

50 JUMPA Volume 7, Nomor 1, Juli 2020 
Steffen, R., deBernardis, C., Baños, A., 2003. Travel epidemiology-a global perspective. Int. J. Antimicrob. Agents 21, 89-95. https://doi.org/https://doi.org/10.1016/S0924-8579(02)00293-5

Tsang, N., Wong, O., Prideaux, B., 2018. An evaluation of the effectiveness of travel advisories with a specific focus on Hong Kong's outbound travel alert system. J. Vacat. Mark. 24, 307-323. https://doi.org/10.1177/1356766717725563

Uraiporn, K., E., M.K., 2009. Socio-demographic constraints to travel behavior. Int. J. Cult. Tour. Hosp. Res. 3, 81-94. https://doi.org/10.1108/17506180910940360

WEF, 2019. The Travel \& Tourism Competitiveness Report 2019.

Yang, S., Cho, S.-I., 2017. Middle East respiratory syndrome risk perception among students at a university in South Korea, 2015. Am. J. Infect. Control 45, e53-e60. https://doi.org/https://doi.org/10.1016/j.ajic.2017.02.013

Ziegler, C.C., 2013. Travel-Related Illness. Crit. Care Nurs. Clin. North Am. 25, 333340. https://doi.org/10.1016/j.ccell.2013.02.015

Zimmer, R., 2012. The pre-travel visit should start with a "risk conversation." J. Travel Med. 19, 277-280. https://doi.org/10.1111/j.1708-8305.2012.00631.x

Zimmermann, R., Hattendorf, J., Blum, J., Nüesch, R., Hatz, C., 2013. Risk Perception of Travelers to Tropical and Subtropical Countries Visiting a Swiss Travel Health Center. J. Travel Med. 20, 3-10. https://doi.org/10.1111/j.17088305.2012.00671.x

Zuckerman, J., Leggat, P.A., 2006. Principles and Practice of Travel Medicine. J. Travel Med. https://doi.org/10.2310/7060.2003.2585

\section{Profil Penulis}

Imam Nur Hakim, S.Sn., adalah seorang peneliti pariwisata di Kementerian Pariwisata dan Ekonomi Kreatif Republik Indonesia. Kepakaran utama penulis adalah pariwisata, sedangkan lingkup ketertarikannya adalah pemasaran dan komunikasi pariwisata. Penulis adalah lulusan S1 Seni Rupa, dan sedang menempuh Pendidikan Magister Manajemen Pemasaran. 